\title{
Altered MicroRNA Expression of Nasal Mucosa in Long-Term Asthma and Allergic Rhinitis
}

\author{
Hille Suojalehto ${ }^{a} \quad$ Irmeli Lindström $^{a}$ Marja-Leena Majuri ${ }^{b} \quad$ Camilla Mitts $^{b}$ \\ Jouko Karjalainenc ${ }^{c}$ Henrik Wolff ${ }^{b}$ Harri Alenius $^{b}$ \\ ${ }^{a}$ Control of Hypersensitivity Diseases Team and b Unit of Systems Toxicology, Finnish Institute of Occupational \\ Health, and ${ }^{\mathrm{C} C e n t r e}$ of Military Medicine, Helsinki, Finland
}

\section{Key Words}

Biomarkers - Cytokines · Asthma - Allergic rhinitis .

MicroRNA

\begin{abstract}
Background: Asthma and allergic rhinitis (AR) commonly coexist and can be taken as manifestations of one syndrome. Evidence exists that microRNAs (miRNAs) are important in controlling inflammatory processes and they are considered promising biomarkers. However, little is known about the differences in miRNA expression in patients with chronic allergic airway disease. This study evaluated the inflammatory and miRNA profiles of the nasal mucosa of patients with long-term asthma with and without AR. Methods: We analyzed inflammatory cells, cytokines, and miRNAs in nasal biopsies and measured exhaled and nasal nitric oxide levels during the nonpollen season in 117 middle-aged men who had suffered mainly from allergic asthma for approximately 20 years and also in 33 healthy controls. Results: The differences in the number of nasal eosinophils and cytokine expression levels were modest in nasal biopsies taken from asthmatics. Downregulation of miR-18a, miR-126, let-7e, miR-155, and miR-224 and upregulation of miR-498, miR187, miR-874, miR-143, and miR-886-3p were observed in
\end{abstract}

asthmatic patients in comparison to controls. The differences in miRNA expression were mainly similar in asthmatics with and without AR. With regard to asthma severity, a trend of increased miRNA expression in persistent asthma was seen, whereas the downregulation of certain miRNAs was most distinct in nonpersistent-asthma patients. Conclusions: Differences in miRNA expression in the nasal mucosa of subjects with long-term asthma and AR can be seen also when no markers of Th2-type inflammation are detected. Asthma severity had only a minor impact on miRNA expression.

(c) 2014 S. Karger AG, Basel

\section{Introduction}

Rhinitis and asthma are highly prevalent chronic diseases [1-3]. They coexist commonly; most patients with asthma suffer from rhinitis and asthma is present in 10$40 \%$ of patients with rhinitis [4]. Asthma has been strongly associated with allergic rhinitis (AR) and also with rhi-

This work was conducted at the Finnish Institute of Occupational Health.

\section{KARGER}

E-Mail karger@karger.com

www.karger.com/iaa (c) 2014 S. Karger AG, Base

$1018-2438 / 14 / 1633-0168 \$ 39.50 / 0$
Correspondence to: Prof. Harri Alenius

Finnish Institute of Occupational Health

Topeliuksenkatu 41 a A

FI-00250 Helsinki (Finland)

E-Mail harri.alenius@ttl.fi 
nitis in nonatopic subjects [5]. The existence and severity of AR have been linked to the severity of the coexisting asthma [6,7], although some studies have not confirmed this association $[8,9]$.

The inflammatory process in the airways displays several common characteristics in asthma and AR, e.g. IgEdependent activation of mast cells, infiltration of eosinophils, and an increase in the number of $\mathrm{Cd} 4+$ lymphocytes and Th-2 type cytokine concentrations [10]. In addition, cytokines associated with regulatory $\mathrm{T}$ cells and Th1 and Th17 cells have been found to be essential. It has been postulated that rhinitis and asthma are manifestations of one syndrome with a wide spectrum of severity and with common underlying inflammatory processes [11]. Eosinophilic infiltration in nasal mucosa has been found in asthma patients without symptoms of rhinitis [12]. On the other hand, no difference in cellular infiltration in nasal mucosa has been observed in rhinitis patients either with or without asthma [13].

In the absence of allergen exposure, no increase in numbers of inflammatory cells, markers of eosinophilic activation, or cell surface adhesion molecule expression have been detected in seasonal AR [14-16]. In addition, in patients with indoor allergy, nasal eosinophilia is not a permanent feature [3]. However, in house dust mite (HDM) allergy, chronic upregulation of the inflammatory cells and mediators has been observed in the nasal cavities of symptom-free AR patients with detectable allergen exposure [17]. Moreover, so-called 'minimal persistent inflammation' in nasal mucosa has been found in symptom-free patients with perennial AR as well as those with seasonal AR, both at the beginning and after the end of the seasonal allergic symptoms [18]. This refers to a subclinical inflammatory state in which an increase in inflammation can be seen after allergen exposures at subthreshold doses which do not result in allergic symptoms.

MicroRNAs (miRNAs) are small noncoding RNAs which act mainly as suppressors of gene expression at the posttranscriptional level and may modulate cell differentiation, proliferation, and survival $[19,20]$. The regulatory miRNA network is complex: a cluster of miRNAs may be controlled by one promoter; alternatively, a single miRNA may be encoded by multiple pre-miRNAs. Similarly, a single messenger RNA (mRNA) may be regulated by many miRNAs and one miRNA may potentially regulate many mRNA transcripts. miRNAs are important regulators in the development and activity of the innate and adaptive immune systems and inflammation $[21,22]$. Recent studies have revealed the critical role of specific
miRNAs in regulating the key pathogenic mechanisms of allergic inflammation, including the polarization of adaptive immune responses and the activation of $\mathrm{T}$ cells, the regulation of eosinophil development, and the modulation of IL-driven epithelial responses [23, 24]. miRNAs have been considered potentially important clinical biomarkers. Furthermore, correcting defects in the miRNA regulatory network may represent a new approach for nonsteroidal anti-inflammatory treatment $[25,26]$. Nevertheless, the clinical data of miRNAs in asthma and rhinitis is limited [23, 24, 27-29]. Compared to controls, no significant differences were detected in miRNA expression in the bronchial biopsies of subjects with mild asthma [27], whereas in the bronchial epithelial cells of asthmatics 24 miRNAs were differentially expressed compared to controls [30]. Also, compared to controls, 9 miRNAs were differentially expressed in the nasal mucosa of AR patients [29].

Even though miRNAs are regarded as promising biomarkers, their role in the airways of subjects with chronic allergic airway disease is obscure. Therefore, we aimed to detect biomarkers in nasal mucosa related to long-term asthma and AR and to evaluate whether these markers could be used as a surrogate measure of asthma severity. The inflammatory differences occurring in the nasal mucosa of asthmatics with or without AR were studied in the absence of seasonal allergen exposure.

\section{Material and Methods}

\section{Study Population}

The study population consisted of men who about 20 years previously had performed their military service. Online supplementary figure S1 (see www.karger.com/doi/10.1159/000358486 for all online suppl. material) and recent articles describe the study population in detail $[31,32]$. The asthma group was comprised of men who during their military service had been referred to the Central Military Hospital between 1986 and 1990 because of asthma. Asthma was verified by a significant reversibility of bronchial obstruction in spirometry, airway hyperresponsiveness in histamine challenge, a positive exercise test, a diagnostic PEF recording, and/or evidence of earlier diagnosed asthma. Controls entered military service without asthma. All of the subjects were examined between 2009 and 2011, approximately 20 years after their military service.

A total of 150 men aged $37-48$ years (mean 41.2 , SD 1.9) participated in this study (online suppl. fig. S1). The characteristics of the subjects are presented in table 1 . A total of $82.1 \%$ of the asthmatics had concomitant AR. Most of the asthmatics were sensitized to both seasonal and perennial allergens. The nonpersistentand persistent-asthma groups did not differ significantly in terms of $\mathrm{AR}$, atopic sensitization, or the number of subjects with visible nasal polyps in anterior rhinoscopy. 
Table 1. Characteristics of the study subjects

\begin{tabular}{|c|c|c|c|c|c|c|c|c|}
\hline & \multirow{2}{*}{$\begin{array}{l}\text { Total } \\
(n=150)\end{array}$} & \multirow{2}{*}{$\begin{array}{l}\text { Control } \\
(n=33)\end{array}$} & \multicolumn{2}{|c|}{ Asthma $(\mathrm{n}=117)$} & \multirow[t]{2}{*}{$\mathrm{p}_{1}$} & \multirow[t]{2}{*}{$\mathrm{p}_{2}$} & \multirow[t]{2}{*}{$\mathrm{p}_{3}$} & \multirow[t]{2}{*}{$\mathrm{p}_{4}$} \\
\hline & & & $\begin{array}{l}\text { nonpersistent } \\
(\mathrm{n}=63)\end{array}$ & $\begin{array}{l}\text { persistent } \\
(\mathrm{n}=54)\end{array}$ & & & & \\
\hline Smokers & $43(28.7)$ & $6(18.2)$ & $16(25.4)$ & $21(38.9)$ & 0.088 & 0.424 & 0.043 & 0.118 \\
\hline BMI & $27.4 \pm 5.0$ & $26.9 \pm 4.5$ & $27.1 \pm 4.4$ & $28.0 \pm 5.9$ & 0.500 & 0.825 & 0.318 & 0.349 \\
\hline AR patients & $96(64.0)$ & $0(0.0)$ & $50(79.4)$ & $46(85.2)$ & $<0.001$ & $<0.001$ & $<0.001$ & 0.413 \\
\hline$>4$ & $88(58.7)$ & $1(3.0)$ & $48(76.2)$ & $39(72.2)$ & & & & \\
\hline \multicolumn{9}{|l|}{ At least 1 positive SPT to } \\
\hline perennial allergens & $94(62.7)$ & $3(9.1)$ & $47(74.6)$ & $44(81.5)$ & $<0.001$ & $<0.001$ & $<0.001$ & 0.372 \\
\hline At least 1 positive SPT to & & & & & & & & \\
\hline seasonal allergens & $100(66.7)$ & $7(21.2)$ & $49(77.8)$ & $44(81.5)$ & $<0.001$ & $<0.001$ & $<0.001$ & 0.621 \\
\hline
\end{tabular}

Values are presented as $\mathrm{n}(\%)$ or means $\pm \mathrm{SD}$. $\mathrm{p}_{1}=\mathrm{p}$ value between the study groups; $\mathrm{p}_{2}=\mathrm{p}$ value between the control and nonpersistent-asthma groups; $\mathrm{p}_{3}=\mathrm{p}$ value between the control and persistent-asthma groups; $\mathrm{p}_{4}=\mathrm{p}$ value between the nonpersistent- and persistent-asthma groups.

This study was approved by the Ethical Committee of the Department of Medicine of Helsinki University Central Hospital (approval No. 284/13/03/00/08). Written informed consent was obtained from the study subjects.

\section{Clinical Examination}

Participants filled out a self-completed questionnaire covering their medical history, validated questions about asthma symptoms and medications in use [33], smoking, and a $10-\mathrm{cm}$ visual analogue scale (VAS) of rhinorrhea, nasal congestion, and nasal itchiness [34]. A respiratory physician and rhinologist interviewed and examined all subjects. A period of 4 weeks without exposure to seasonal allergens before the visit was required. Nasal medication including nasal steroids, and oral steroids were withheld for 14 days and antihistamines for 7 days before the examination if possible (10 subjects had a shorter period after cessation of these medications). Subjects reporting feverish respiratory infection or symptoms of sinusitis in the previous 4 weeks were excluded from the analysis.

\section{Assessment of $A R$ and Asthma Severity}

At least one positive skin prick test (SPT) and relevant rhinitis symptoms to allergen showing a positive reaction confirmed current AR. If dermographismus occurred, specific IgE verified sensitization. AR during military service was assessed based on the medical records of the Central Military Hospital if the data was available; $93.3 \%$ of subjects with current disease had AR already during military service.

Asthma severity was classified according to the Global Initiative for Asthma as a combination of the independent classifications of clinical severity (including $\mathrm{FEV}_{1}$ and symptoms) and med- ication [35]. This scale was described in detail in a recent article [32]. The following categories were used to describe asthma severity: remission, intermittent, mild persistent, moderate persistent, and severe persistent. Remission was defined as having no asthma symptoms and not using any asthma medication in the last 3 years. The numbers (\%) of subjects in each category were: remission, 13 (7.7); intermittent, 50 (33.3); mild persistent, 13 (8.7); moderate persistent, 25 (16.7), and severe persistent, 16 (10.7). Because of the small number of subjects in each category, they were combined as follows: (1) nonpersistent asthma including remission and intermittent asthma and (2) persistent asthma including mild, moderate, and severe persistent asthma. Seven subjects (11\%) in the nonpersistent-asthma group and $6(11 \%)$ in the persistent-asthma group had used nasal steroids in the preceding 4 weeks; 1 subject $(2 \%)$ in the persistent-asthma group had used oral steroids in the preceding 4 weeks. In the nonpersistent-asthma group, 11 subjects $(17 \%)$ had used a short-acting bronchodilator, 3 subjects $(5 \%)$ had inhaled steroids, and 2 subjects (3\%) had used a combination of inhaled steroids and a long-lasting bronchodilator in the preceding weeks; in the persistent-asthma group 30 (56\%), 16 (30\%), and 11 subjects (20\%) had used asthma medication, respectively.

\section{IgE Measurements and SPT}

Serum total and specific IgEs were measured using the Phadia UniCAP System (Phadia, Uppsala, Sweden). Total IgE $<110 \mathrm{kU} / \mathrm{l}$ and specific $\operatorname{IgE}<0.35 \mathrm{kU} / \mathrm{l}$ were regarded as normal. The SPT panel included a negative control, a positive control (histamine), and standardized antigens of birch, alder, timothy grass, meadow fescue, orchard grass and mugwort pollen, Alternaria alternata, Cladosporium herbarum, cat and dog epithelium, and HDM Dermatophagoides pteronyssimus (ALK-Abello, Nieuwegein, The 


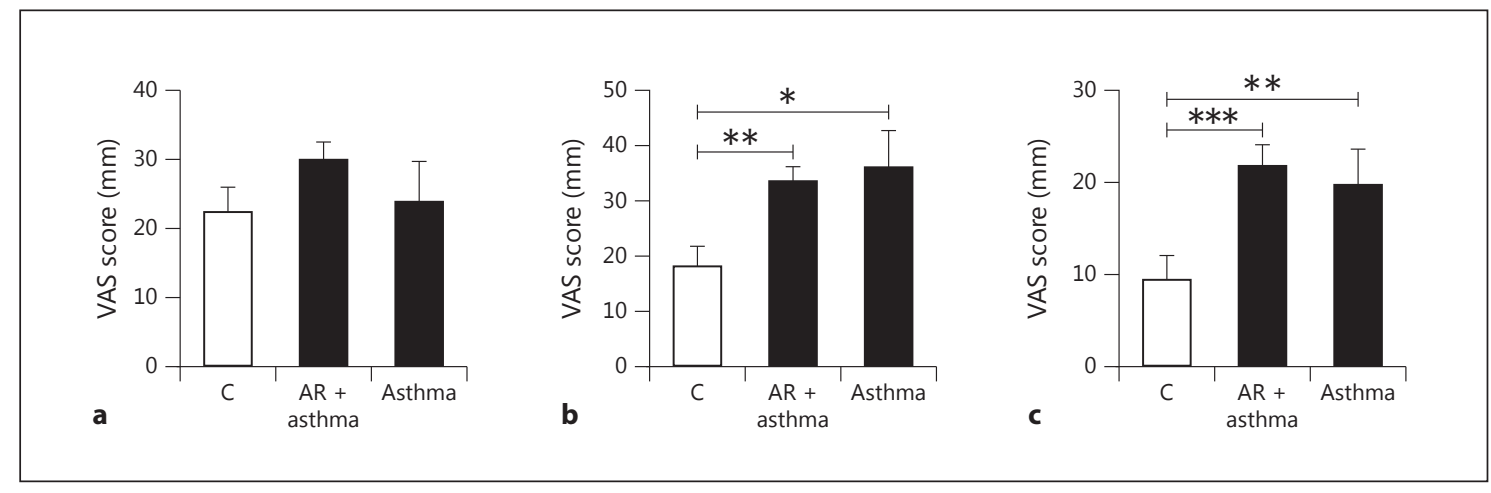

Fig. 1. VAS scores of nasal congestion and itching are increased in subjects with asthma despite AR. VAS scores of rhinorrhea (a), nasal congestion (b), and nasal itching (c) in controls (C), subjects with allergic AR and asthma (AR + asthma), and asthmatics without concomitant AR (asthma). The columns and error bars represent means \pm SEM. ${ }^{*} \mathrm{p}<0.05{ }^{* *} \mathrm{p}<0.01{ }^{* * *} \mathrm{p}<0.001$.

Netherlands). Results were regarded as positive if the mean wheal diameter was at least $3 \mathrm{~mm}$ without any reaction to the negative control (dermographismus).

\section{Lung Function and Nitric Oxide Measurements}

Flow volume spirometry and a bronchodilation test were performed according to the guidelines [36] with a standard spirometer (Spirostar USB; Medikro, Finland). The predicted values assessed for the Finnish population were used.

Exhaled $\left(\mathrm{FE}_{\mathrm{NO}}\right)$ and nasal nitric oxide $\left(\mathrm{N}_{\mathrm{NO}}\right)$ were measured using an online chemiluminescence analyzer (NIOX; Aerocrine $\mathrm{AB}$, Solna, Sweden) in compliance with ATS/ERS recommendations [37].

\section{Histology of Nasal Biopsies}

Nasal biopsies obtained from the anterosuperior part of the inferior conchae were fixed in $10 \%$ buffered formalin and embedded in paraffin. Sections of $2.5 \mu \mathrm{m}$ were cut and stained with hematoxylin and eosin and examined under a light microscope (Leica DM LB; Wetzlar, Germany). Eosinophils were counted in 3 highpower fields at a $\times 400$ magnification.

\section{Real-Time Quantitative RT-PCR and miRNA Assay}

Quickly frozen nasal biopsies were kept at $-70^{\circ} \mathrm{C}$ before the extraction of RNA. Total RNA was extracted using TRIsure reagent (Bioline; Taunton, Mass., USA) according to the manufacturer's protocol. The total amount of RNA was measured with a NanoDrop ND-1000 spectrophotometer (NanoDrop Technologies Inc., Wilmington, Del., USA). The mRNA expressions of cytokines IL-4, IL-5, IL-13, IL-17A, and IFN- $\gamma$ were measured as described earlier [38].

The quantification of miRNAs by TaqMan real-time PCR was carried out as described by the manufacturer (Applied Biosystems). The target gene expression was normalized between different samples based on the values of RNU48 small nuclear RNA expression. Results were analyzed using SDS 1.4 software according to the $2^{-\Delta \Delta C T}$ method (Applied Biosystems) as described earlier [39]. We analyzed the expressions of miR-7, miR-
143, miR-187, miR-224, miR-498, miR-767-5p, miR-874 and miR-886-3p, let-7e, miR-18a, miR-126, miR-146a, miR-155, and miR-205.

\section{Statistical Analysis}

Continuous variables are expressed as means $( \pm \mathrm{SD})$ and categorical values as percentages. Differences between groups, in the case of 3 or more groups, were analyzed using Kruskal-Wallis, ANOVA, and $\chi^{2}$ tests, depending on the distribution. The post hoc tests for continuous variables were Student's t test or the MannWhitney $U$ test. The analyses for miRNAs were also rerun while adjusted for smoking. In that case, these covariates and the particular parameter to be studied were set as independent variables, and group membership was the dependent variable in a multinomial logistic regression model. $\mathrm{p}<0.05$ was considered statistically significant. Spearman's correlation was computed between variables. The statistical analysis was performed using IBM SPSS Statistics 20 software (SPSS Inc., Chigago, Ill., USA).

\section{Results}

\section{Inflammatory Markers and miRNAs in $A R$ and Asthma}

When asthmatics with $\mathrm{AR}$ (AR + asthma) and without AR (asthma) were separately analyzed and compared to controls, we found an increase in the level of nasal congestion and nasal itching in both asthma groups (fig. 1), but no difference was detected between the two asthma groups. The level of total serum IgE was elevated in the $\mathrm{AR}+$ asthma group but not in the asthma without AR group (fig. 2a). In contrast, the numbers of blood eosinophils were increased in both asthma groups. The level of $\mathrm{FE}_{\mathrm{NO}}$ was elevated in the $\mathrm{AR}+$ asthma group compared 


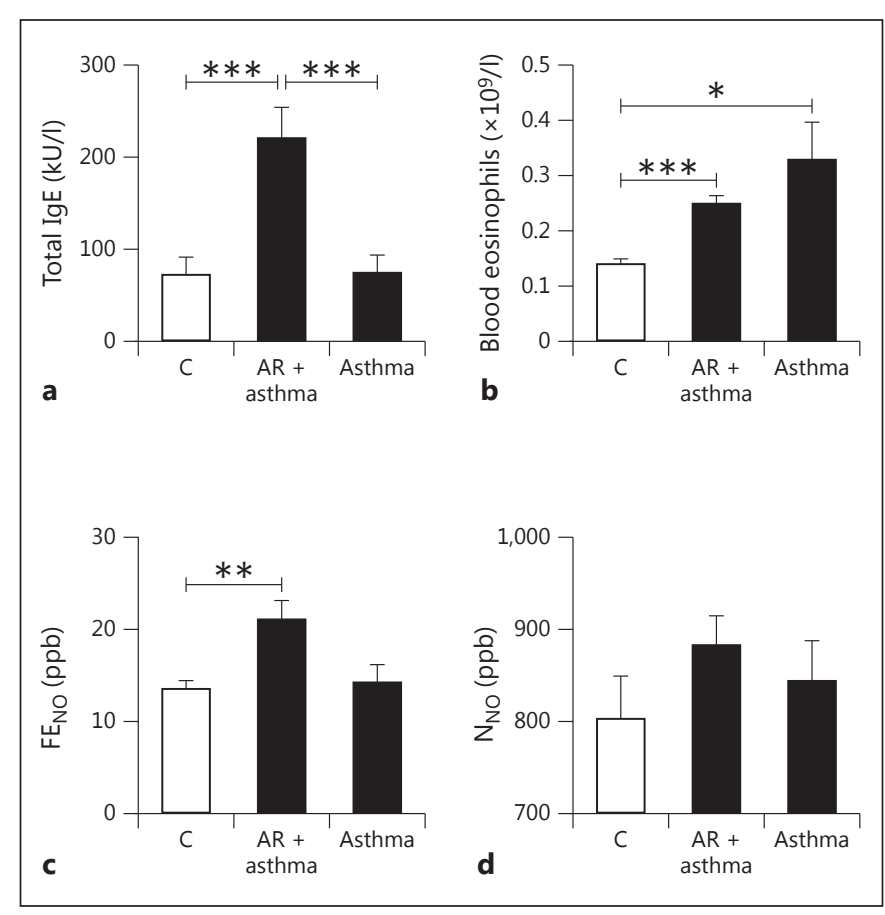

Fig. 2. Blood eosinophils are increased in asthmatics with and without AR. Serum total $\operatorname{IgE}$ (a) and blood eosinophil count (b) and $\mathrm{FE}_{\mathrm{NO}}(\mathbf{c})$ and $\mathrm{N}_{\mathrm{NO}}(\mathbf{d})$ in in controls $(\mathrm{C})$, subjects with $\mathrm{AR}$ and asthma (AR + asthma), and asthmatics without concomitant AR (asthma). The columns and error bars represent means \pm SEM. ${ }^{*} \mathrm{p}<0.05$; $^{* *} \mathrm{p}<0.01 ;{ }^{* * *} \mathrm{p}<0.001$. to controls and a similar trend was seen in the level of $\mathrm{N}_{\mathrm{NO}}$ (fig. 2b). No difference in the nasal eosinophil count was found between the studied groups (data not shown). In order to clarify the cytokine profile in nasal mucosa, the mRNA levels of Th2, Th1, and Th17 cytokines were assayed and a reduced amount of IFN- $\gamma$ mRNA was detected in the nasal mucosa of asthmatics (online suppl. fig. S2a). No statistically significant differences were detected in the other cytokines examined.

We analyzed the expressions of 8 miRNAs formerly identified as being differentially expressed in AR, i.e. miR-7, miR-143, miR-187, miR-224, miR-498, miR-767$5 p$, miR-874, and miR-886-3p [29]. In addition, we assayed 6 miRNAs claimed to be related to allergic inflammatory or immunological responses in earlier studies, i.e. let-7e, miR-18a, miR-126, miR-146a, miR-155, and miR205. Aberrant expressions were detected in 5 of the miRNAs (fig. 3). The expressions of miR-18a, miR-126, and miR-155 were similarly downregulated in both asthma groups. Instead, upregulation in miR-498 and miR187 was most prominent in the AR + asthma group. The differences in miRNA expressions between study groups when adjusted for smoking are presented in online supplementary table S1a. We detected an increased level of miR-498 in the nasal mucosa of subjects with perennial allergy (SPT positive to one or more perennial allergens)

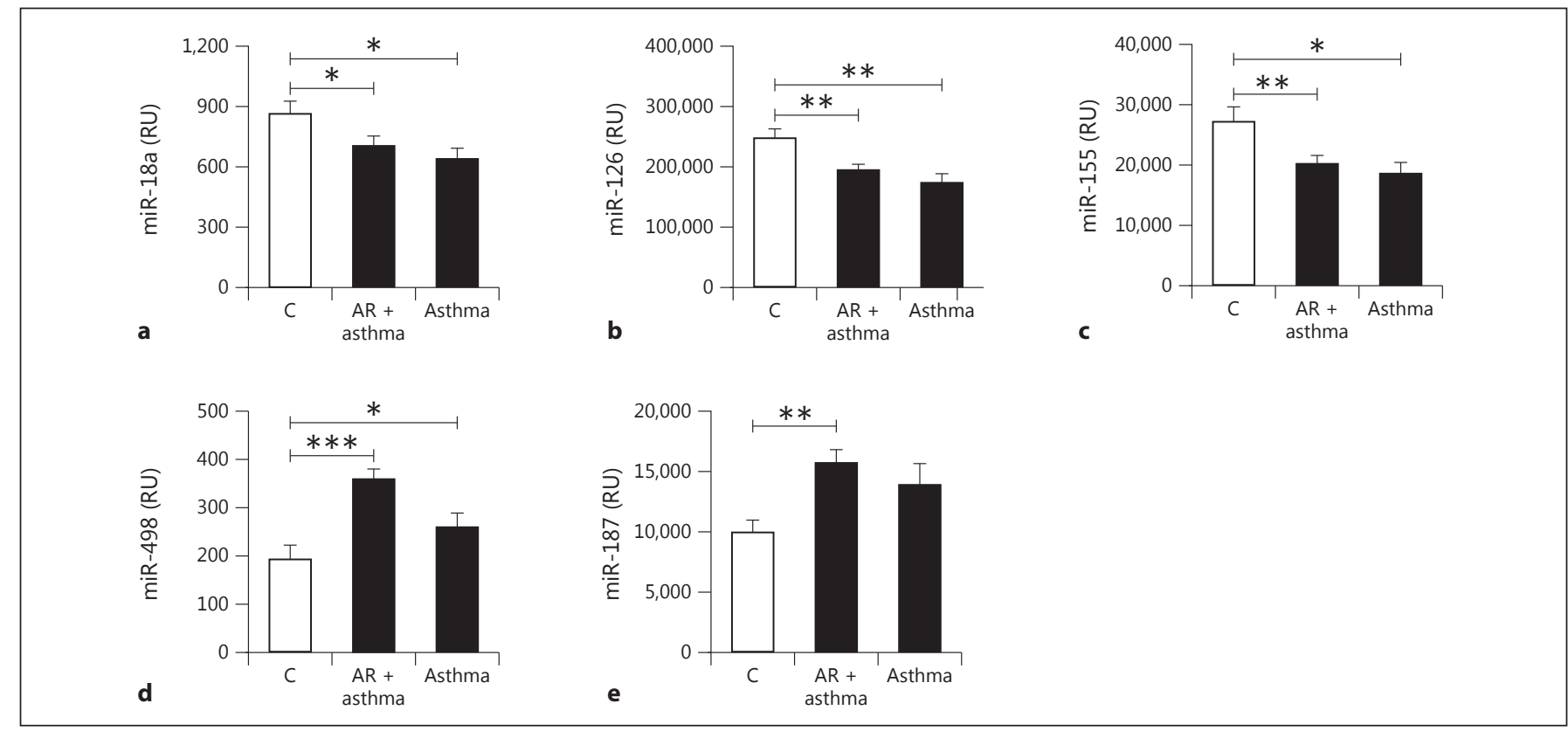

Fig. 3. Five microRNAs have altered expressions in nasal mucosa in AR. Expressions of miR-18a (a), miR-126 (b), miR-155 (c), miR498 (d), and miR-187 (e) in controls (C), subjects with AR and asthma (AR + asthma), and asthmatics without concomitant AR (asthma). Results are shown in relative units (RU). The columns and error bars represent means \pm SEMs. ${ }^{*} \mathrm{p}<0.05 ;{ }^{* *} \mathrm{p}<0.01$; ${ }^{* * *} \mathrm{p}<0.001$. 


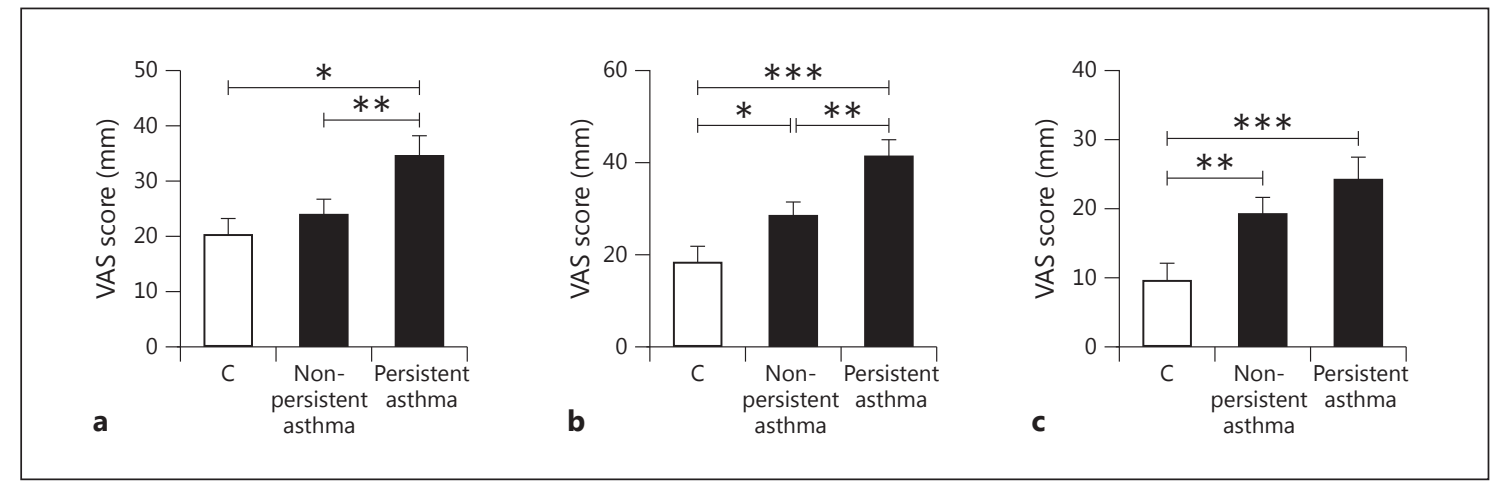

Fig. 4. VAS scores of rhinorrhea, nasal congestion, and itching are increased in persistent asthma. VAS scores of rhinorrhea (a), nasal congestion (b), and nasal itching (c) in controls (C), subjects with asthma remission or intermittent asthma (nonpersistent asthma), and subjects with mild, moderate, or severe persistent asthma (persistent asthma). The columns and error bars represent means \pm SEM. ${ }^{*} \mathrm{p}<0.05 ;{ }^{* *} \mathrm{p}<0.01{ }^{* * *} \mathrm{p}<0.00$.

compared to subjects with negative SPT results $(\mathrm{p}=$ 0.020). miR-18a expression was significantly lower in subjects with perennial allergy compared to subjects with sensitization to seasonal allergens only $(\mathrm{p}=0.036)$.

\section{Inflammatory Markers and miRNAs in Nonpersistent and Persistent Asthma}

Next we analyzed subjects with nonpersistent asthma and those with persistent asthma separately and compared these groups with controls. All of the nasal symptoms, i.e. rhinorrhea, congestion, and itching, were most prominent in the persistent-asthma group (fig. 4). The level of total IgE was equally elevated in both asthma groups, whereas the number of blood eosinophils and the level of $\mathrm{FE}_{\mathrm{NO}}$ were highest in the persistent-asthma group (fig. 5). No difference was detected in the number of nasal eosinophils (data not shown). The level of IFN- $\gamma$ mRNA in nasal mucosa was reduced in both asthma groups (online suppl. fig. S2b). No significant differences were detected in the concentrations of Th2 or Th17 cytokines.

Altogether, 10 miRNAs of the 14 studied were differentially expressed in asthmatics compared to controls (fig. 6). The miRNA expressions in subjects with nonpersistent asthma were not clearly different from those of patients with persistent asthma. However, the levels of 5 miRNAs (miR-18a, miR-126, let-7e, miR-155, and miR224) were more distinctly downregulated in the nonpersistent-asthma group; the downregulation was less prominent in persistent asthma. In contrast, the upregulation of 5 miRNAs (miR-498, miR-187, miR-874, miR-143, and miR-886-3p) was more explicit in the persistentasthma group. The cytokine and miRNA expressions of

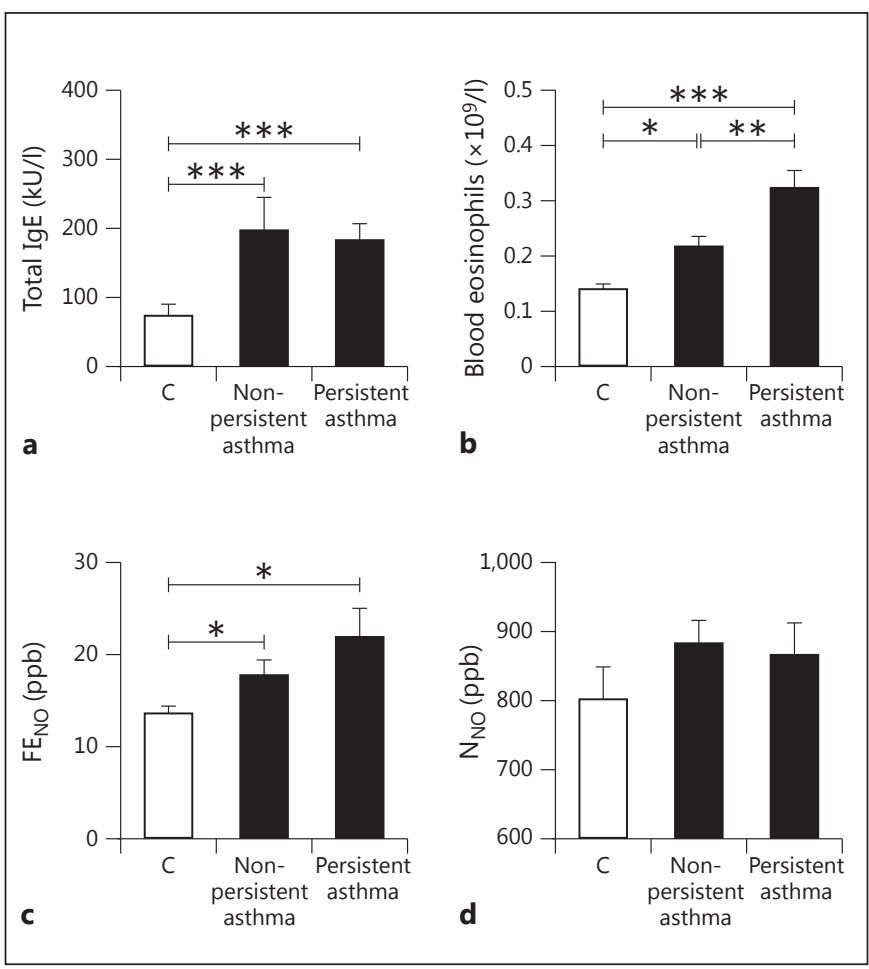

Fig. 5. Blood eosinophils are increased in persistent asthma. Serum total $\operatorname{IgE}(\mathbf{a})$ and blood eosinophil count $(\mathbf{b})$ and $\mathrm{FE}_{\mathrm{NO}}(\mathbf{c})$ and $\mathrm{N}_{\mathrm{NO}}$ (d) in controls (C), subjects with asthma remission or intermittent asthma (nonpersistent asthma), and subjects with mild, moderate, or severe persistent asthma (persistent asthma). The columns and error bars represent means \pm SEM. ${ }^{*} \mathrm{p}<0.05 ;{ }^{* *} \mathrm{p}<0.01$; ${ }^{* * *} \mathrm{p}<$ 0.001 . 


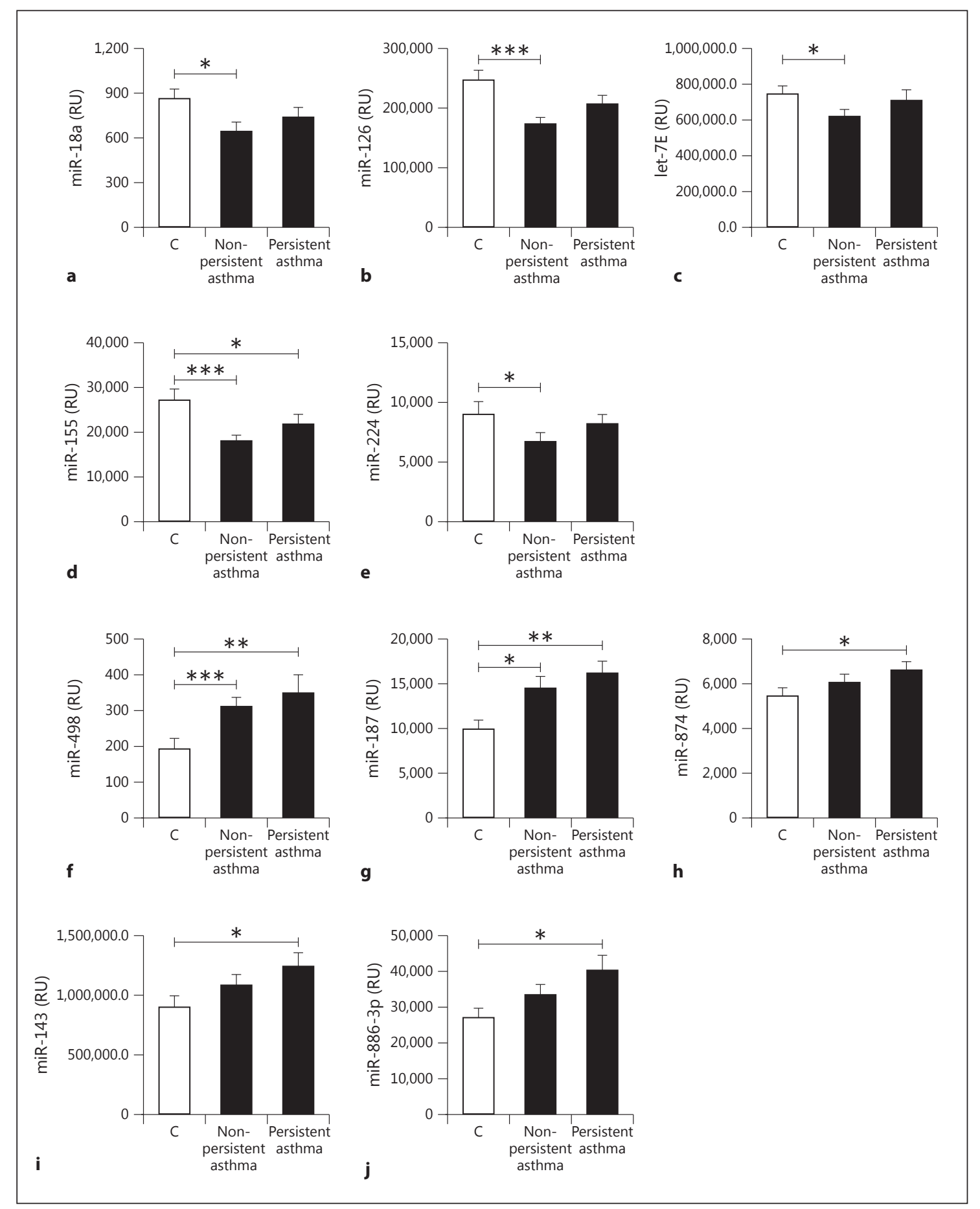

Fig. 6. Ten microRNAs are aberrantly expressed in the nasal mucosa of asthmatics. Expressions of miR-18a (a), miR-126 (b), let-7E (c), miR-155 (d), miR-224 (e), miR-498 (f), miR-187 (g), miR-874 (h), miR-143 (i), and miR886-3p (j) in controls (C), subjects with asthma remission or intermittent asthma (nonpersistent asthma), and subjects with mild, moderate, or severe persistent asthma (persistent asthma). Results are shown in relative units (RU). The columns and error bars represent means \pm SEM. ${ }^{*} \mathrm{p}<0.05 ;{ }^{* *} \mathrm{p}<0.01 ;{ }^{* *} \mathrm{p}<0.001$. 
the individual asthma severity categories (remission, intermittent, mild persistent, and severe persistent) and the controls are presented in online supplementary table S2. The differences between miRNA expressions in these study groups when adjusted for smoking are presented in online supplementary table S1b.

mir-155 Correlates with $\mathrm{FE}_{N O}$ and $\mathrm{N}_{N O}$ and Th2

Cytokines and miR-498 with IFN- $\gamma$ in Asthmatics

In asthmatics, miR-155 positively correlated with $\mathrm{FE}_{\mathrm{NO}}(\mathrm{r}=0.317, \mathrm{p}=0.001), \mathrm{N}_{\mathrm{NO}}(\mathrm{r}=0.358, \mathrm{p}<0.001)$, and IL-13 mRNA $(r=0.380, p<0.001)$ (online suppl. fig. S3). In addition, a weak positive correlation between miR-155 and $\operatorname{IgE}(r=0.212, p=0.024)$ was detected and furthermore MiR-498 inversely correlated with IFN- $\gamma$ $(\mathrm{r}=-0.385, \mathrm{p}<0.001)$.

\section{Discussion}

In this study, we analyzed inflammatory markers and miRNAs in the nasal mucosa of well-characterized patients with long-term asthma with or without AR during the nonpollen season. No differences were seen in Th2type inflammatory markers. We detected aberrant expressions of 10 miRNAs in nasal mucosa. The differences in miRNA expressions were mainly similar in asthmatics with and without AR. With regard to asthma severity, a trend towards increased miRNA expression of 5 miRNAs in persistent asthma was seen, whereas the downregulation of 5 miRNAs was most distinct in subjects with nonpersistent asthma.

The study population originated from a follow-up survey and represents middle-aged men. It is homogenous with regard to age, nationality, and sex; thus, there are few confounding factors. Little is known about the role of gender differences in miRNA expression among asthmatics. Our study subjects represented men with earlyonset asthma and therefore our results cannot be generalized to females or to adult-onset asthma cases. The asthma severity was classified reliably based on symptoms, lung function, and asthma treatment evaluation. The asthmatics had clinically verified disease already in young adulthood, with most of them belonging to the allergic asthma phenotype with concomitant AR, and they were sensitized to both perennial and seasonal allergens [39]. A smaller proportion $(17.9 \%)$ of asthmatics did not have concomitant AR; however, 8 subjects in that group had at least 1 positive SPT to a common environmental allergen. Although these subjects suffered no AR symptoms, we

Nasal miRNA Profiles in Asthma and AR cannot exclude the possibility that there was some allergic inflammation in the nasal mucosa. The subjects were examined during the nonpollen season without exposure to seasonal allergens and their VAS scores of nasal symptoms were mainly low, suggesting that we were evaluating chronic differences in nasal mucosa rather than acute allergic reactions. Based on former studies, nasal and systemic steroids were withdrawn 14 days before the examination $[29,40]$. Only 13 subjects had used these medications during the preceding 28 days and no significant differences in any of the miRNAs were detected in these subjects compared to those not using these medications (data not shown). We did not exclude from this study subjects with visible nasal polyps in anterior rhinoscopy $(n=7)$. These subjects belong to a different phenotype than subjects with AR and asthma [41]. A comparison of asthmatics with and without nasal polyps showed no significant differences in any of the examined cytokines or miRNAs (data not presented).

Asthmatics with or without AR had more nasal congestion and itching than controls. This finding supports the results of Leynaert et al. [5] who showed that rhinitis is associated with asthma also in nonatopic subjects. In the persistent-asthma group, the nasal symptom scores were significantly higher than in the nonpersistent-asthma group. In some studies asthma severity has been associated with rhinitis severity $[7,42]$, whereas in others the link between asthma and rhinitis severity has been less clear [9]. In our study, the number of blood eosinophils was increased in asthmatics despite concurrent $\mathrm{AR}$, this being more prominent in the persistent-asthma group. In earlier studies, both an increased level of blood eosinophils [43] and eosinophilic airway inflammation were associated with more severe asthma [44]. Nitric oxide is a marker of inflammation in the upper and lower airways [45]. The $\mathrm{FE}_{\mathrm{NO}}$ level was elevated in subjects with asthma and AR compared to the controls, whereas this was not seen in asthmatics without AR. This finding indicates that eosinophilic airway inflammation was more prominent in subjects with concomitant AR [46]. Only a trend towards elevation was detected in $\mathrm{N}_{\mathrm{NO}}$ in asthmatics with $\mathrm{AR}$, supporting previous findings that $\mathrm{N}_{\mathrm{NO}}$ is not elevated in AR during the nonpollen season [47].

We did not detect any increase in the number of eosinophils or in Th2 or Th17 cytokine concentrations in nasal mucosa. This is in agreement with previous studies in which no increase in the number of inflammatory cells, markers of eosinophilic activation, or cell surface adhesion molecules in seasonal AR were observed in the 
absence of environmental allergen exposure [14-16]. On the other hand, in HDM-sensitized AR patients, inflammation in nasal mucosa has been detected in symptomfree subjects [17]. In the current study, most of the asthmatics had perennial allergy, but only a minority of them (14.2\%) were sensitized to HDM. An increase in the number of IFN- $\gamma$-producing cells in the bronchial biopsies of severe asthmatics compared to moderate asthmatics was demonstrated by Shannon et al. [48]. In contrast, IFN- $\gamma$ mRNA was downregulated in the nasal mucosa of asthmatics compared to controls and a trend towards a decrease was seen in the present study in subjects with more severe asthma. It should be noted, however, that in the study of Shannon et al. [48] asthmatics had more severe diseases and they were not compared to healthy controls.

We found downregulation of 5 miRNAs (miR-18a, miR-126, let-7e, miR-155, and miR-224) and upregulation of 5 miRNAs (miR-498, miR-187, miR-874, miR143 , and miR-886-3p) in the nasal biopsies of asthma patients compared to controls. In general, the differences in miRNA expressions were modest, which is in line with former studies in asthmatics and patients with $\operatorname{AR}[27,40$, 49]. We found an altered expression of 6 miRNAs (miR224, miR-498, miR-187, miR-874, miR-143, and miR886-3p) formerly identified as exhibiting 2-fold differences in expression in AR compared to controls [29]. Interestingly, 5 of the upregulated miRNAs in the present study were downregulated in the study of Shaoqing et al. [29]. The different patient material may have influenced the results; we examined subjects during the nonpollen season when they were experiencing only mild symptoms, whereas in the study of Shaoqing et al. [29] the subjects underwent surgery for nasal obstruction and current exposure to allergens was not reported. In our study as a whole, the differences in observed miRNA expressions were similar in asthmatics with and without AR. This is in line with previous reports of a persistent presence of inflammatory cells in nasal mucosa in asthmatics independently of rhinitis [12]. No significant differences in these miRNAs were detected between asthma severity groups; however, with respect to the upregulated miRNAs, a tendency was seen towards a more increased expression in the persistent-asthma group compared to their nonpersistent counterparts.

Some of the miRNAs which were differentially expressed in nasal mucosa in this study have been identified previously to be involved in the regulation of allergic inflammation. MiR-155 plays an important role in host defense and in the function of $\mathrm{B}$ and $\mathrm{T}$ lymphocytes and dendritic cells $[50,51]$ and it modulates the IL-13 pathway in human macrophages determining the M2 phenotype [52]. Upregulation of miR-155 has been shown in asthma and atopic dermatitis [23]. In the present study, miR-155 expression levels were downregulated in asthmatics in comparison to controls. We also found a weak correlation between the expression level of miR-155 and both $\mathrm{FE}_{\mathrm{NO}}$ and $\mathrm{N}_{\mathrm{NO}}$ as well as Th2 cytokine levels in asthmatics. In our previous study, we found an increase in miR-155 levels in subjects with current AR symptoms, but asthmatics and subjects without current symptoms did not differ from the controls [40]. Our results might suggest that the expression of miR-155 in active allergic inflammation is different from that in the chronic stage. It has been previously reported that, in HDM-induced allergic mice, inhibition of miR-126 could suppress Th2 type airway inflammation, airway hyperresponsiveness, and mucus hypersecretion [53]. In the present study, the expression of miR-126 was suppressed in the nonpersistent-asthma group. Information about the role of miR-498 in inflammation is exiguous. Shaoqing et al. [29] reported downregulation of miR-498 in the nasal mucosa in AR. In contrast, in the present study we detected elevated levels of miR-498 in asthmatics with or without AR. Our findings are in line with our previous study in which we found upregulation of miR-498 in subjects with current AR symptoms [40]. Cigarette smoke has previously been shown to cause dysregulation (mainly downregulation) of some miRNAs in human airway epithelium $[54,55]$. Smoking had some effect on our results; statistically significant differences between study groups were detected in most of the presented miRNAs (miR-18a, miR-126, miR-155, miR-498, miR-187, and miR-886-3p) after adjusting for smoking, whereas in let-7E, miR-224, miR-874, and $\mathrm{miR}-143$ the differences between study groups were borderline significant.

In conclusion, we examined differences in nasal mucosa in subjects who had suffered from asthma and AR for 20 years. We did not detect differences in the numbers of nasal eosinophils or the levels of Th2 cytokines, reflecting the low allergen exposure and low symptom score level. However, we found altered expressions of $10 \mathrm{miRNAs}$, of which miR-155, miR-126, and let-7 have been formerly revealed to be essential in regulating allergic inflammation. In addition to AR and asthma, upregulation of miR498 was associated with perennial allergy. Interestingly, miRNA expression in nasal mucosa in long-term asthmatics was similar in subjects with or without concomitant AR. In summary, the differences in miRNA expres- 
sions were not significant in asthmatics in terms of asthma severity, although a tendency towards greater differences was seen in those subjects with more severe asthma. miRNAs may be sensitive markers of chronic inflammation in the airways and in the future they may be useful in phenotyping these patients.

\section{Acknowledgements}

We thank Outi Fischer and the study nurses for their assistance in this study.

\section{References}

1 Masoli M, Fabian D, Holt S, Beasley R: The global burden of asthma: executive summary of the GINA Dissemination Committee report. Allergy 2004;59:469-478.

$\checkmark 2$ Pallasaho P, Juusela M, Lindqvist A, Sovijarvi A, Lundback B, Ronmark E: Allergic rhinoconjunctivitis doubles the risk for incident asthma - results from a population study in Helsinki, Finland. Respir Med 2011;105: 1449-1456.

- 3 Bousquet J, Khaltaev N, Cruz AA, Denburg J, Fokkens WJ, Togias A, Zuberbier T, BaenaCagnani CE, Canonica GW, van Weel C, Agache I, Ait-Khaled N, Bachert C, Blaiss MS, Bonini S, Boulet LP, Bousquet PJ, Camargos P, Carlsen KH, Chen Y, Custovic A, Dahl R, Demoly P, Douagui H, Durham SR, van Wijk RG, Kalayci O, Kaliner MA, Kim YY, Kowalski ML, Kuna P, Le LT, Lemiere C, Li J, Lockey RF, Mavale-Manuel S, Meltzer EO, Mohammad Y, Mullol J, Naclerio R, O'Hehir RE, Ohta K, Ouedraogo S, Palkonen S, Papadopoulos N, Passalacqua G, Pawankar R, Popov TA, Rabe KF, Rosado-Pinto J, Scadding GK, Simons FE, Toskala E, Valovirta E, van Cauwenberge $\mathrm{P}$, Wang DY, Wickman M, Yawn BP, Yorgancioglu A, Yusuf OM, Zar H, Annesi-Maesano I, Bateman ED, Ben Kheder A, Boakye DA, Bouchard J, Burney P, Busse WW, Chan-Yeung $\mathrm{M}$, Chavannes $\mathrm{NH}$, Chuchalin A, Dolen WK, Emuzyte R, Grouse L, Humbert M, Jackson C, Johnston SL, Keith PK, Kemp JP, Klossek JM, LarenasLinnemann D, Lipworth B, Malo JL, Marshall GD, Naspitz C, Nekam K, Niggemann B, Nizankowska-Mogilnicka E, Okamoto Y, Orru MP, Potter P, Price D, Stoloff SW, Vandenplas O, Viegi G, Williams D: Allergic Rhinitis and its Impact on Asthma (ARIA) 2008 update (in collaboration with the World Health Organization, GA(2)LEN and AllerGen). Allergy 2008;63(suppl 86):8-160.

4 Cruz AA, Popov T, Pawankar R, Annesi-Maesano I, Fokkens W, Kemp J, Ohta K, Price D, Bousquet J: Common characteristics of upper and lower airways in rhinitis and asthma: ARIA update, in collaboration with GA(2) LEN. Allergy 2007;62(suppl 84):1-41.

5 Leynaert B, Bousquet J, Neukirch C, Liard R, Neukirch F: Perennial rhinitis: an independent risk factor for asthma in nonatopic subjects - results from the European Community Respiratory Health Survey. J Allergy Clin Immunol 1999;104:301-304.
6 Magnan A, Meunier JP, Saugnac C, Gasteau J, Neukirch F: Frequency and impact of allergic rhinitis in asthma patients in everyday general medical practice: a French observational cross-sectional study. Allergy 2008;63:292298.

7 Ponte EV, Franco R, Nascimento HF, SouzaMachado A, Cunha S, Barreto ML, Naspitz C, Cruz AA: Lack of control of severe asthma is associated with co-existence of moderate-tosevere rhinitis. Allergy 2008;63:564-569.

8 de Marco R, Marcon A, Jarvis D, Accordini S, Almar E, Bugiani M, Carolei A, Cazzoletti L, Corsico A, Gislason D, Gulsvik A, Jogi R, Marinoni A, Martinez-Moratalla J, Pin I, Janson C: Prognostic factors of asthma severity: a 9-year international prospective cohort study. J Allergy Clin Immunol 2006;117: 1249-1256.

-9 Antonicelli L, Braschi MC, Bresciani M, Bonifazi M, Baldacci S, Angino A, Pala AP, Viegi G: The complex link between severity of asth$\mathrm{ma}$ and rhinitis in mite allergic patients. Respir Med 2013;107:23-29.

10 Barnes PJ: Pathophysiology of allergic inflammation. Immunol Rev 2011;242:31-50.

11 Togias A: Rhinitis and asthma: evidence for respiratory system integration. J Allergy Clin Immunol 2003;111:1171-1183, quiz 1184.

12 Gaga M, Lambrou P, Papageorgiou N, Koulouris NG, Kosmas E, Fragakis S, Sofios C, Rasidakis A, Jordanoglou J: Eosinophils are a feature of upper and lower airway pathology in non-atopic asthma, irrespective of the presence of rhinitis. Clin Exp Allergy 2000;30: 663-669.

13 Lambrou P, Zervas E, Oikonomidou E, Papageorgiou N, Alchanatis M, Gaga M: Eosinophilic infiltration in the nasal mucosa of rhinitis patients: is it affected by the presence of asthma or the allergic status of the patients? Ann Allergy Asthma Immunol 2007;98:567572.

14 Juliusson S, Pipkorn U, Karlsson G, Enerback L: Mast cells and eosinophils in the allergic mucosal response to allergen challenge: changes in distribution and signs of activation in relation to symptoms. J Allergy Clin Immunol 1992;90:898-909.

15 Ciprandi G, Pronzato C, Ricca V, Passalacqua G, Bagnasco M, Canonica GW: Allergen-specific challenge induces intercellular adhesion molecule 1 (ICAM-1 or CD54) on nasal epithelial cells in allergic subjects: relationships with early and late inflammatory phenomena. Am J Respir Crit Care Med 1994;150:16531659.

16 Milanese M, Ricca V, Canonica GW, Ciprandi G: Eosinophils, specific hyperreactivity and occurrence of late phase reaction in allergic rhinitis. Eur Ann Allergy Clin Immunol 2005; 37:7-10.

17 Ciprandi G, Buscaglia S, Pesce G, Pronzato C, Ricca V, Parmiani S, Bagnasco M, Canonica GW: Minimal persistent inflammation is present at mucosal level in patients with asymptomatic rhinitis and mite allergy. J Allergy Clin Immunol 1995;96:971-979.

18 Canonica GW, Compalati E: Minimal persistent inflammation in allergic rhinitis: implications for current treatment strategies. Clin Exp Immunol 2009;158:260-271.

19 Bartel DP: MicroRNAs: genomics, biogenesis, mechanism, and function. Cell 2004;116: 281-297.

20 Guo H, Ingolia NT, Weissman JS, Bartel DP: Mammalian microRNAs predominantly act to decrease target mRNA levels. Nature 2010; 466:835-840

21 Xiao C, Rajewsky K: MicroRNA control in the immune system: basic principles. Cell 2009; 136:26-36.

22 O'Connell RM, Rao DS, Chaudhuri AA, Baltimore D: Physiological and pathological roles for microRNAs in the immune system. Nat Rev Immunol 2010;10:111-122.

$23 \mathrm{Lu}$ TX, Rothenberg ME: Diagnostic, functional, and therapeutic roles of microRNA in allergic diseases. J Allergy Clin Immunol 2013;132:3-13.

24 Rupani H, Sanchez-Elsner T, Howarth P: MicroRNAs and respiratory diseases. Eur Respir J 2013;41:695-705.

25 Wang JW, Li K, Hellermann G, Lockey RF, Mohapatra S: Regulating the regulators: microRNA and asthma. World Allergy Organ J 2011;4:94-103.

26 Greene CM, Gaughan KP: microRNAs in asthma: potential therapeutic targets. Curr Opin Pulm Med 2013;19:66-72.

27 Williams AE, Larner-Svensson H, Perry MM, Campbell GA, Herrick SE, Adcock IM, Erjefalt JS, Chung KF, Lindsay MA: microRNA expression profiling in mild asthmatic human airways and effect of corticosteroid therapy. PLoS One 2009;4:e5889.

28 Jiang X: The emerging role of microRNAs in asthma. Mol Cell Biochem 2011;353:35-40. 
-29 Shaoqing Y, Ruxin Z, Guojun L, Zhiqiang Y, Hua H, Shudong Y, Jie Z: Microarray analysis of differentially expressed microRNAs in allergic rhinitis. Am J Rhinol Allergy 2011; 25:e242-e246.

- 30 Jardim MJ, Dailey L, Silbajoris R, Diaz-Sanchez D: Distinct microRNA expression in human airway cells of asthmatic donors identifies a novel asthma-associated gene. Am J Respir Cell Mol Biol 2012;47:536-542.

- 31 Lindstrom I, Pallasaho P, Luukkonen R, Suojalehto H, Karjalainen J, Lauerma A, Karjalainen A: Reduced work ability in middleaged men with asthma from youth - a 20-year follow-up. Respir Med 2011;105:950-955.

- 32 Lindstrom I, Suojalehto H, Lindholm H, Pallasaho P, Luukkonen R, Karjalainen J, Lauerma A, Karjalainen A: Positive exercise test and obstructive spirometry in young male conscripts associated with persistent asthma 20 years later. J Asthma 2012;49:1051-1059.

- 33 Kilpelainen M, Terho EO, Helenius H, Koskenvuo M: Validation of a new questionnaire on asthma, allergic rhinitis, and conjunctivitis in young adults. Allergy 2001;56:377-384.

- 34 Spector SL, Nicklas RA, Chapman JA, Bernstein IL, Berger WE, Blessing-Moore J, Dykewicz MS, Fineman SM, Lee RE, Li JT, Portnoy JM, Schuller DE, Lang D, Tilles SA: Symptom severity assessment of allergic rhinitis. 1. Ann Allergy Asthma Immunol 2003;91:105-114.

- 35 Liard R, Leynaert B, Zureik M, Beguin FX, Neukirch F: Using global initiative for asthma guidelines to assess asthma severity in populations. Eur Respir J 2000;16:615-620.

- 36 Miller MR, Hankinson J, Brusasco V, Burgos F, Casaburi R, Coates A, Crapo R, Enright P, van der Grinten CP, Gustafsson P, Jensen R, Johnson DC, MacIntyre N, McKay R, Navajas D, Pedersen OF, Pellegrino R, Viegi G, Wanger J: Standardisation of spirometry. Eur Respir J 2005;26:319-338.

-37 ATS/ERS recommendations for standardized procedures for the online and offline measurement of exhaled lower respiratory nitric oxide and nasal nitric oxide, 2005. Am J Respir Crit Care Med 2005;171:912-930.

- 38 Kankkunen P, Rintahaka J, Aalto A, Leino M, Majuri ML, Alenius $\mathrm{H}$, Wolff $\mathrm{H}$, Matikainen S: Trichothecene mycotoxins activate inflammatory response in human macrophages. J Immunol 2009;182:6418-6425.
39 Agache I, Akdis C, Jutel M, Virchow JC: Untangling asthma phenotypes and endotypes. Allergy 2012;67:835-846.

40 Suojalehto H, Toskala E, Kilpelainen M, Majuri M-L, Mitts C, Lindström I, Puustinen A, Plosila T, Sipilä J, Wolff H, Alenius H: microRNA profiles in nasal mucosa of patients with allergic and nonallergic rhinitis and asthma. Int Forum Allergy Rhinol 201;3:612-620.

41 Zhang YN, Cao PP, Zhang XH, Lu X, Liu Z: Expression of microRNA machinery proteins in different types of chronic rhinosinusitis. Laryngoscope 2012;122:2621-2627.

42 Navarro A, Valero A, Julia B, Quirce S: Coexistence of asthma and allergic rhinitis in adult patients attending allergy clinics: ONEAIR study. J Investig Allergol Clin Immunol 2008; 18:233-238.

43 Bousquet J, Chanez P, Lacoste JY, Barneon G, Ghavanian N, Enander I, Venge P, Ahlstedt S, Simony-Lafontaine J, Godard P, Michel F-B: Eosinophilic inflammation in asthma. N Engl J Med 1990;323:1033-1039.

44 Louis R, Lau LC, Bron AO, Roldaan AC, Radermecker M, Djukanovic R: The relationship between airways inflammation and asthma severity. Am J Respir Crit Care Med 2000; 161:9-16.

45 Sahin G, Klimek L, Mullol J, Hörmann K, Walther LE, Pfaar O: Nitric oxide: a promising methodological approach in airway diseases. Int Arch Allergy Immunol 2011;156: 352-361.

46 Dweik RA, Boggs PB, Erzurum SC, Irvin CG, Leigh MW, Lundberg JO, Olin AC, Plummer AL, Taylor DR: An official ATS clinical practice guideline: interpretation of exhaled nitric oxide levels $\left(\mathrm{FE}_{\mathrm{NO}}\right)$ for clinical applications. Am J Respir Crit Care Med 2011;184:602615.

47 Henriksen AH, Sue-Chu M, Holmen TL, Langhammer A, Bjermer L: Exhaled and nasal no levels in allergic rhinitis: relation to sensitization, pollen season and bronchial hyperresponsiveness. Eur Respir J 1999;13:301306.
48 Shannon J, Ernst P, Yamauchi Y, Olivenstein R, Lemiere C, Foley S, Cicora L, Ludwig M, Hamid Q, Martin JG: Differences in airway cytokine profile in severe asthma compared to moderate asthma. Chest 2008;133:420-426.

49 Sjogren AK, Barrenas F, Muraro A, Gustafsson $M$, Saetrom $P$, Wang $H$, Benson M: Monozygotic twins discordant for intermittent allergic rhinitis differ in mRNA and protein levels. Allergy 2012;67:831-833.

50 Rodriguez A, Vigorito E, Clare S, Warren MV, Couttet P, Soond DR, van Dongen S, Grocock RJ, Das PP, Miska EA, Vetrie D, Okkenhaug K, Enright AJ, Dougan G, Turner M, Bradley A: Requirement of bic/microRNA-155 for normal immune function. Science 2007;316:608-611.

51 Kohlhaas S, Garden OA, Scudamore C, Turner M, Okkenhaug K, Vigorito E: Cutting edge: The Foxp3 target miR-155 contributes to the development of regulatory T cells. J Immunol 2009;182:2578-2582.

52 Martinez-Nunez RT, Louafi F, Sanchez-Elsner T: The interleukin 13 (IL-13) pathway in human macrophages is modulated by microRNA-155 via direct targeting of interleukin 13 receptor alpha1 (IL13ralpha1). J Biol Chem 2011;286:1786-1794.

53 Mattes J, Collison A, Plank M, Phipps S, Foster PS: Antagonism of microRNA-126 suppresses the effector function of TH2 cells and the development of allergic airways disease. Proc Natl Acad Sci USA 2009;106:1870418709.

54 De Flora S, Balansky R, D’Agostini F, Cartiglia C, Longobardi M, Steele VE, Izzotti A: Smoke-induced microRNA and related proteome alterations: Modulation by chemopreventive agents. Int J Cancer 2012;131;27632773.

55 Schembri F, Sridhar S, Perdomo C, Gustafson AM, Zhang X, Ergun A, Lu J, Liu G, Zhang X, Bowers J, Vaziri C, Ott K, Sensinger K, Collins JJ, Brody JS, Getts R, Lenburg ME, Spira A: MicroRNAs as modulators of smoking-induced gene expression changes in human airway epithelium. Proc Natl Acad Sci USA 2009;106:2319-2324. 